\title{
Cytological Effects of Water Extracts of Medicinal Plants in Egypt Mitotic disturbances induced by water extract of Cymbopogon proximus (Halfa barr) on Vicia faba
}

\author{
Zakia M. Adam ${ }^{1}$ and Odette R. Farah ${ }^{2}$ \\ 'Botany Department, Women's Coll. of Arts, Sci. and Educ. Ain Shams \\ Univ., Heliopolis, Cairo, Egypt \\ ${ }^{2}$ Laboratory of Genetics and Cytology, National Research Centre, \\ Dokki, Cairo, Egypt
}

Accepted September 21, 1988

Because of the ever increasing use of water extracts of medicinal plants in curing diseases instead of the synthetic drugs, care must be taken to avoid harmful effect which may arise from wrong or extra usage. The cytological effects of the crude water extracts of medicinal plants may cause undesired heritable changes. Some cytologists tried to investigate the response of dividing cells to plant extracts, among them Keck and Hoffmann-Ostenhof (1951), Kato (1957), Tarkowska (1971), Shehab and Adam (1981, 1983), Adam and Rashad (1984, 1985) and Adam and El-Nahas (1988).

In this survey, the mitotic effect of Cymbopogon proximus extract was studied on roots of Vicia faba. Cymbopogon proximus (Halfa barr), is a perennial aromatic grass belonging to family Gramineae. It is widely grown in upper Egypt (Täckholm 1974). The grass extract is used by the inhabitants as carminative, diuretic and urinary antiseptic.

\section{Materials and methods}

The plant extract was prepared by boiling 1, 2 and $3 \mathrm{gm}$ of Cymbopogon proximus in $100 \mathrm{ml}$ tap water for 10 minutes. The evaporated water was replaced by tap water to original volume $(100 \mathrm{ml})$. The extract was decanted while hot.

Vicia faba seeds, v. Giza 2, were sown in sawdust. When the roots were $1.5-3 \mathrm{~cm}$ in length, they were treated with the different concentrations of the extract $(1,2$ and $3 \%)$ for 4 hours. Tap water was used for the control experiment.

Another group of Vicia faba roots were immersed in $1 \%$ extract for 24 and 48 hours. The $1 \%$ concentration is commonly used for preparation of Cymbopogon proximus beverage (tea spoonful/200 $\mathrm{ml}$ water).

Three replicates, three roots/each were used for each treatment. After treatments, the roots were cut and fixed in Carnoy's fixative. Observations were made from permanent leuco basic fuchsion stained preparations. Mitotic index (MI) was calculated as the number of dividing cells/1000 counted cells. The data were analyzed according to the t-test.

\section{Results and discussion}

The data scored in Table 1 showed that all treatments affected MI negatively, the decline was not significant in short hours of treatment (4 hours). The effect was slightly signicant in roots treated for 24 hours and highly significant after 48 hours treatment with $1 \%$ extract. Other plant extracts proved to be mitodepressive such as water extracts of: Sonchus, Chenopodium, Crisum and Medicago (Bukolova and Stepanova 1972), Lupinus termis extract (Shehab 
and Adam 1981) and Datura innoxia and Hyoscyamus muticus extract (Shehab et al. 1983).

The results show that the reduced mitotic activity may be ascribed to partial blockage of DNA synthesis, thus minimizing the number of cells entering mitosis rather than hindering spindle formation. Table 1 showed also that analysis of frequency of mitotic phases points to a preprophasic action. It manifested itself in the decrease of the number of nuclei entering prophase. This effect leads to increase in percentage of metaphases and ana- and telophases over those of the control in some treatments. Kubiak (1966) ascribed the increased percentages of phases to be due to prolonged duration of it.

Table 1. Mitotic index and frequency of the mitotic stages in Vicia faba roots treated with Cymbopogon proximus extract

\begin{tabular}{|c|c|c|c|c|c|c|c|c|}
\hline \multirow[b]{2}{*}{ Treatment } & \multicolumn{3}{|c|}{ Interphase cells } & \multirow{2}{*}{$\begin{array}{l}\text { No. of } \\
\text { dividing } \\
\text { cells }\end{array}$} & \multirow{2}{*}{ MI \pm S.E. } & \multicolumn{3}{|c|}{ Mitotic stages } \\
\hline & Total & $\begin{array}{l}\text { No. } \\
\text { abn. }\end{array}$ & $\begin{array}{l}\% \\
\text { abn. }\end{array}$ & & & Prophase & Metaphase & $\begin{array}{c}\text { Ana- } \\
\text { telophase } \%\end{array}$ \\
\hline \multicolumn{9}{|c|}{ I. Root-treatment for $4 \mathrm{hrs}$. with: } \\
\hline 1. $3 \% \mathrm{ext}$ & 9751 & 521 & 5.31 & 819 & $77.44 \pm 13.46$ & 43.03 & 24.99 & 31.97 \\
\hline 2. $2 \%$ ext. & 9235 & 122 & 1.31 & 818 & $81.26 \pm 4.15$ & 42.13 & 23.89 & 33.99 \\
\hline 3. $1 \%$ ext. & 9150 & 56 & 0.61 & 780 & $78.50 \pm 5.66$ & 44.49 & 27.38 & 28.13 \\
\hline Control & 9569 & 68 & 0.67 & 1024 & $96.60 \pm 4.04$ & 45.89 & 22.25 & 31.86 \\
\hline \multicolumn{9}{|c|}{ II. Root-treatment with $1 \%$ ext. for: } \\
\hline 1. $24 \mathrm{hrs}$. & 9000 & 12 & 0.13 & 532 & $55.80 \pm 2.21$ & 37.87 & 24.04 & 38.10 \\
\hline Control & 9000 & 7 & 0.08 & 789 & $80.48 \pm 7.60$ & 45.81 & 24.43 & 29.75 \\
\hline 2. $48 \mathrm{hrs}$. & 9000 & 3 & 0.03 & 368 & $39.27 * * 2.83$ & 28.77 & 31.14 & 40.09 \\
\hline Control & 9000 & 2 & 0.02 & 648 & $67.15 \pm 2.25$ & 40.07 & 22.93 & 37.00 \\
\hline
\end{tabular}

** Significant to control at 0.01 level of probability (t-test).

Table 2. Total percentage of abnormalities and its distribution in the mitotic stages of Vicia faba treated with Cymbopogon proximus extract

\begin{tabular}{|c|c|c|c|c|c|c|}
\hline \multirow[b]{2}{*}{ Treatment } & \multicolumn{3}{|c|}{ Dividing cells } & \multicolumn{3}{|c|}{$\%$ of abn. in mitotic stages } \\
\hline & Total & $\begin{array}{l}\text { No. } \\
\text { abn. }\end{array}$ & $\begin{array}{c}\% \\
\text { abn. }\end{array}$ & Prophase & Metaphase & $\begin{array}{c}\text { Ana- } \\
\text { telophase }\end{array}$ \\
\hline \multicolumn{7}{|c|}{ 1. Root-treatment for 4 hrs. with: } \\
\hline 1. $3 \%$ ext. & 819 & 156 & $20.27^{*}+4.78$ & 1.62 & 33.38 & 33.86 \\
\hline 2. $2 \%$ ext. & 818 & 151 & $18.70^{* *} \pm 1.93$ & 0.55 & 32.58 & 31.42 \\
\hline 3. $1 \%$ ext. & 780 & 108 & $13.89 * * \pm 1.70$ & 0.55 & 27.80 & 21.22 \\
\hline Control & 1024 & 17 & $1.67 \pm 0.23$ & 0.18 & 3.58 & 2.78 \\
\hline \multicolumn{7}{|c|}{ II. Root-treatment with $1 \%$ ext. for: } \\
\hline 1. 24 hrs. & 532 & 162 & $30.62 * * \pm 2.20$ & 16.24 & 48.68 & 33.60 \\
\hline Control & 789 & 36 & $4.61 \pm 0.50$ & 1.43 & 7.45 & 8.06 \\
\hline 2. $48 \mathrm{hrs}$. & 368 & 134 & $36.71^{* *} \pm 2.48$ & 21.32 & 69.96 & 23.01 \\
\hline Control & 648 & 31 & $4.84 \pm 2.00$ & 4.56 & 4.01 & 5.69 \\
\hline
\end{tabular}

* Significant to control at 0.05 level of probability (t-test).

** Significant to control at 0.01 level of probability (t-test).

Table 2 indicates that all treatments with the extract induced significant percentage of abnormal dividing cells, its values increased with increase of concentration and time of treatments. The maximum percentage of abnormal dividing scored was $36.71 \%$ after 48 hour treatment with $1 \%$ extract, and the least was $13.89 \%$ after 4 hour treatment with $1 \%$ extract. It was also obvious that metaphase stage was the most affected and the least was prophase stage.

These results led us to opine that Cymbopogon proximus extract has an accumulative effect in induction of chromosomal abnormalities. From Table 3 it is evident that the most fre- 
quent types of irregularities, occured in the form of sticky chromosomes (Fig. 1) resulting from liqueifaction of the chromatin material. This effect leads to hinderance of norma! separation. A maximum value attained $(72.39 \%$ ) followed 48 hour treatment with $1 \%$ extract. Disturbancy of chromosome orientation, either in metaphase (Fig. 2) or anaphase, was also a common abnormality which may be the result of affecting the centromere activity or the spindle fibres.

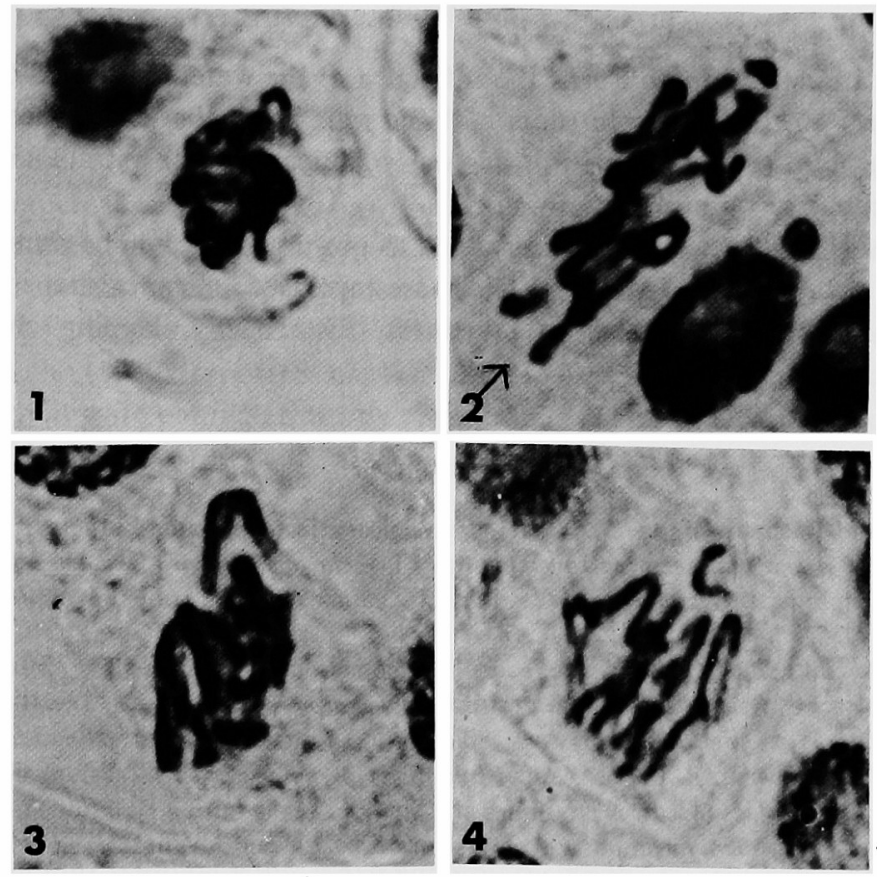

Figs. 1-4. Abnormal mitosis of $V$. faba root cells treated with extract of $C$. proximus. 1, sticky metaphase (for $48 \mathrm{hrs}$ with $1 \%$ extract). 2, disturbed metaphase (for 4 hrs with $2 \%$ extract); arrow, interphase with micronucleous, right. 3, lagging chromosome in metaphase (for 4 hrs with $2 \%$ extract). 4 , lagging chromosome in anaphase (for 4 hrs with $1 \%$ extrat).

Table 3. Percentage of the different types of abnormalities relative to the number of abnormal dividing cells in Vicia faba after treatment with Cymbopogon proximus extract

\begin{tabular}{|c|c|c|c|c|c|c|c|c|}
\hline Treatment & $\begin{array}{l}\text { No. of } \\
\text { abn. } \\
\text { dividing } \\
\text { cells }\end{array}$ & $\underset{\%}{\text { Stick. }}$ & $\begin{array}{c}\text { Dist. } \\
\%\end{array}$ & $\begin{array}{c}\text { Lag. } \\
\%\end{array}$ & $\underset{\%}{\text { Brid. }}$ & $\underset{\%}{\operatorname{Despiral}}$ & $\begin{array}{c}\text { Diagonal } \\
\text { anaph. } \\
\% \\
\%\end{array}$ & $\underset{\%}{\text { Frag. }}$ \\
\hline \multicolumn{9}{|c|}{ I. Root-treatment for $4 \mathrm{hrs}$. with: } \\
\hline 1. $3 \%$ ext. & 156 & 69.23 & 16.03 & 7.05 & 7.05 & - & - & 0.64 \\
\hline 2. $2 \%$ ext. & 151 & 29.80 & 45.03 & 13.25 & 9.93 & - & - & 1.99 \\
\hline 3. $1 \%$ ext. & 108 & 57.41 & 25.93 & 10.19 & 6.48 & - & - & - \\
\hline \multicolumn{9}{|c|}{ II. Root-treatment with $1 \%$ ext. for: } \\
\hline 1. 24 hrs. & 162 & 54.32 & 23.46 & 2.47 & 3.70 & 16.10 & - & - \\
\hline 2. $48 \mathrm{hrs}$. & 134 & 72.39 & 15.67 & 0.75 & 0.75 & 3.73 & 6.72 & - \\
\hline
\end{tabular}

Similar results were reported by Adam and Rashad (1985) treating Vicia faba root tip cells with Ammi visnaga water extract. Selim et al. (1981) refered this type of abnormality to be formed due to spindle interruptions caused by treatment with synthetic organic insecticides. Lagging chromosomes in metaphase (Fig. 3) and anaphase (Fig. 4) and chromosome bridges were also observed but with lower frequencies. Despiralization, diagonal orientation of chro- 
mosomes and chromosome fragmentation were scarcely scored in some treatments (Table 3).

The present results revealed that Cymbopogon proximus extract resembles other plant extracts which induce mitotic irregularities specially on increasing concentration and time of treatment. In this respect it resembles the so called mitotic poisons (D'Amato 1954).

\section{Summary}

The present investigation concerns the influence of the water extract of Cymbopogon proximus (Halfa barr) on the mitosis in roots of Vicia faba. All the used concentrations caused mitotic delay, the action of the long durations was significant. The extract also brought about significant percentage of abnormal dividing cells.

The effect of the extract may be determined as pre-prophasic. The number of prophases decreased while metaphase and ana- and telophase increased. The extract induced a number of chromosomal irregularities such as stickiness, disturbacny, lagging chromosomes and bridges.

\section{References}

Adam, Zakia, M. and Rashad, Thuria, M. 1984. Cytological effects of water extracts of medicinal plants I. Influence of Ammi majus extract on root tips of Vicia faba. Cytologia 49: 265-271.

- and - 1985. Cytological effects of water extracts of Ammi visnaga on root tips of Vicia faba. Egypt $\mathbf{J}$. Bot. 28: 27-35.

- and El-Nahas, Awatif 1988. Cytological effects of medicinal plants in Egypt IX. Mitotic irregularities in Allium cepa root meristem cells treated with Gomphocarpus sinaicus (Hargal) extract. Ann. Rev. Ain Shams Univ. Women's College of Arts, Science and Education, Science Section No. 14: 219-230.

Bukolova, T. and Stepanova L. P. 1972. Antimitotic effect of plant extracts. Tsitol. Genet. 6: 455.

D'Amato, F. 1954. Action des facteures physiques et chimiques sur la mitose II. Huitième Congrès Intern. de Botanique. Paris, 1954. Rapports et communication parvenus avant le congres aux sections 9 et 10.

Kato, Y. 1957. Chromosome breaks and bridge induced by extracts from spinach and beet fruits. Phyton (Argentina) 8: 131-136.

Keck, K. and Hoffmann-Ostenhof, O. 1951. Pflanzliche Stoffwechselprodukte als Mitosegifte. I. Mitosehemmende und -störende Substanzen in wässerigen auszügen aus Allium cepa (Speisezwiebel). Montash. Chem. 82: 559-562.

Kubiak, R. 1966. Mitotic disturbances induced by extracts of Merulius lacrymans. Acta Biologica Cracav 11: $155-169$.

Selim, A. R., Hussein, M. M., Allam, H. Z. and Farag, A. R. 1981. The effect of three synthetic organic insecticides (Nuvacron, Cyolane and Kelthane/Dimethoate) on the cytological characters in cotton Gossypium barbadense L. Bull. Fac. Agric. Cairo Univ. 32: 52-66.

Shehab, Amal, S. and Adam, Zakia, M. 1981. Cytological effect of water extract of Lupinus termis on Vicia faba. Res. Bull. Fac. Agric. Ain-Shams Univ., Cairo, Egypt 1439: 1-14.

- and - 1983. Cytological effects of water extracts of Anastatica hierochuntica L. on Allium cepa. Cytologia 48: 343-348.

-, - and El-Sedawy, A. I. 1983. Meiotic disorders induced by water extracts of Datura innoxia and Hyoscyamus muticus and their active ingredients in Vicia faba PMCs. Annals Agric. Sci. Fac. Agric. AinShams Univ. 28: 1593-1603.

Täckholm, Vivi. 1974. Student's Flora of Egypt. Second Edition. Pub. Cairo Univ. Print. Cooperative Printing Company, Beirut. p. 759.

Tarkowska, J. A. 1971. Antimitotic action of Nerium oleander. Hereditas 67: 205. 